\title{
School Building Energy Assessment Using Lean Energy Management Strategies
}

\begin{abstract}
Abdul Hadi Ahamad ${ }^{1}$, Nur IzieAdiana Abidin ${ }^{*}$, Rozana Zakaria ${ }^{1}$, Eeydzah Aminudin ${ }^{1}$, Jam Shahzaib Khan ${ }^{2}$, Shaza Rina Sahamir ${ }^{3}$, Shamila Azman ${ }^{1}$, Amir Alhamdi Redzuan ${ }^{4}$, Santi Edra Nisa Lau ${ }^{1}$ and Mohamad Faiz Mohd Yusoff ${ }^{5}$

${ }^{1}$ School of Civil Engineering, Faculty of Engineering, Universiti Teknologi Malaysia, Johor Bahru, Malaysia, ${ }^{2}$ Department of Civil Engineering, Quaid-e Awam University of Science and Technology, Nawabshah, Pakistan, ${ }^{3}$ Centre of Studies for Construction, Faculty of Architecture, Planning and Surveying, Universiti Teknologi MARA, Shah Alam, Malaysia, ${ }^{4}$ Malaysia-Japan International Institute of Technology, Universiti Teknologi Malaysia, Jalan Sultan Yahya Petra, Kuala Lumpur, Malaysia, ${ }^{5}$ Energy Efficiency and Conservation Unit, Industry Operations, Energy Commission, Putrajaya, Malaysia
\end{abstract}

In Malaysia, there are approximately 10,220 active schools, and these schools' electricity bills are under the responsibility of the Malaysian Ministry of Education. The demand for energy use is expected to rise dramatically in the coming years due to many factors such as the increasing number of student enrolments and the demand for a comfortable indoor environment in response to global climate effects. Therefore, there are many ideas, concepts, and technologies that have been introduced towards energy conservation in buildings. This study aims to identify key implementation of energy conservation measures and audit energy consumption of five secondary schools. Case studies derived were from schools that participated in Energy Efficiency Challenge hosted by the Energy Commission. It was found that the schools' usage of electricity exceeded their need. Based on the implementation of energy management conservation measures throughout 2016 to 2019, there were gradual reductions and downtrends in energy consumption graphs.

Keywords: energy audit, energy reduction, energy efficiency, energy management, school building, school retrofit, occupant behavior

\section{INTRODUCTION}

The fast-growing world energy consumption has increased concerns overs supply difficulties, depletion of energy resources, adverse health effects, and serious environmental impacts, specifically in developing countries (Belaid and Zrelli, 2019). Therefore, the world is now facing an unprecedented energy challenge, even if all Energy Efficiency (EE) policies are implemented with grand success. Global primary energy demand is expected to increase by $35 \%$ by 2040 (Doulos et al., 2019). Despite that, the International Energy Agency had indicated that one-third of the world's energy requirements could be reduced by the year 2050 by focusing on improving EE in high energyconsuming sectors such as the construction, industrial, commercial, and transportation sectors (Rakhshan and Friess, 2017).

In Malaysia, the Ministry of Science, Technology and Innovation (MOSTI) have taken several measures to promote further EE in line with the increase of the Malaysian population estimated at 32.73 million people in the year 2021, with a growth of $2.38 \%$ since the year 2019 (Norazman et al., 2021). Energy demand is expected to increase, parallel and proportioned to the increase of 
population growth and economic development (Belussi et al., 2019). Since Malaysia is highly dependent on fossil fuel to generate electricity, for instance, the usage of oil, gas, and coal, the exploitation of these natural resources needs to be mitigated, as these resources become very limited due to their scarcity (Stabile et al., 2019). On top of that, continued usage of these natural resources will lead to greenhouse gases, thus depleting the ozone layer (Evangelisti et al., 2020). It is estimated that by the year 2030, 40 billion tons of carbon will be produced if there are no serious efforts made to reduce Carbon Dioxide $\left(\mathrm{CO}_{2}\right)$ emissions (Paola et al., 2021). More policies were announced, such as National Petroleum Policy (1975), National Energy Policy (1979), National Depletion Policy (1980), Fifth Fuel Policy (2000), Energy Commission Act (2001), National Biofuel Policy (2006), and New Economic Model (2009), as an effort to reduce depletion of natural resources and to move towards sustainable development at a national scale (Karunakaran and Verayiah, 2017).

In order to achieve Sustainable Development Goals (SDGs), it is critical for every sector, including industrial, residential, and commercial, to have a sustainable environment (Wong et al., 2018). The fourth goal of SDG, "excellent education," requires a concentration on educational buildings such as schools, colleges, and universities (Kamaruzaman et al., 2017). The proper comfort and efficiency levels in educational facilities may increase the productivity of students, teachers, and lecturers (Bae et al., 2020). As a result, classrooms are viewed as an integral part of the learning process and area. Due to the disruptive study environment, insufficient environmental classroom circumstances will reflect students' motivation and success (David et al., 2017). According to Chao et al. (2020), the physical environment of classrooms can impact students' performance and accomplishment. Classrooms should be meticulously planned, including lighting and ventilation, in order to achieve the best possible physical environment (Jiang et al., 2018).

Based on Malaysian Standards 1525 (Energy Efficiency and Use of Renewable Energy for Non-Residential Buildings), minimum lighting for classrooms should have at least 300 lux of illuminance (Norazman et al., 2018). In terms of ventilation, there should not be less than $10 \%$ of continuous airflow through openings such as windows (Suhaimi et al., 2017). Apart from the physical surroundings, the cleanliness of the classroom is another important aspect that might impact a student's wellbeing and comfort level (Sadick and Issa, 2017). Chinaza (2020) specified that dusty classrooms can cause discomfort, which might affect students' focus and motivation. Furthermore, Najafi et al. (2018) said that impurities in the classroom will impact students' stress levels. Healthy learning spaces for students, which are mostly supported through school facilities, are synonymous with academic and learning growth (Li et al., 2018). Lighting, fans, air conditioning, laptops, kettles, and other school equipment are utilized by students and teachers during the school day, which reflects the energy usage (Khalil et al., 2018).

Malaysian commercial buildings contribute $13.6 \%$ to the nation's total energy consumption and $48 \%$ of its electricity consumption (Mazlan et al., 2020). However, improving EE practices in commercial buildings can attain the most significant benefits in terms of energy and environmental impact. Before improving building EE, energy usage patterns must be extracted to be analyzed. This is obtained by examining the buildings' EE, through the assessment of benchmarking, which is a technique for comparing a building's performance with that of its building stock (Geraldi et al., 2021). An energy audit will be performed in this research as part of the benchmarking process to assess the EE of government schools in Malaysia, as well as possible energy reduction and cost savings (Yuanda et al., 2019). An energy audit is a way of determining how much energy a building or electrical equipment utilizes (AlAjlan, 2018). It is a technique for evaluating how much energy is consumed in a building in a methodical way. An energy audit could identify the overall amount of energy consumed and, if necessary, the energy consumption of various pieces of equipment. This will assist in stimulating decision-making in conservation energy measures that need to be implemented in that particular building (Merabtine et al., 2018).

Researchers in many countries conducted various studies on energy audits, which indicates interest in this topic internationally. One of the audits, in Marrone et al. (2018), was conducted on an educational building in Kuwait, a hot climate country. They utilized a similar energy audit approach to obtain information on the potential energy savings that could be produced. According to the findings, adjustments in lighting and equipment usage schedules can save $6.5 \%$ of energy. Moreover, a $2.3 \%$ reduction can be realized by changing the type of lighting. If all the recommendations are taken into account, a whopping $53 \%$ of energy can be saved. A study was also carried out on 28 school buildings as part of the Serbia Energy Efficient Project. Their research focuses solely on building heat consumption, which is achieved by obtaining the goal of increasing EE (El-Darwish and Gomaa, 2017). The research achieved a $49 \%$ decrease in energy usage, going from 252 to $128 \mathrm{kWh} / \mathrm{m}^{2} /$ year. According to another study by Umberto et al. (2017), changing windows reduces heat transfer losses by $20 \%$.

A school building in Tehran, wall and roof retrofit with insulation installed, and replacing the window system achieved an energy reduction of $44.1 \%$ (Tahsildoost and Zomorodian, 2015). The study employed a building simulation model to forecast and encourage the implementation of energy conservation measures. Other research utilized similar approaches to determine the possible reduction in energy consumption from the adoption of energy conservation measures when compared with the original energy consumption (Meilboudi et al., 2017). Another research of high schools in central Italy found that applying some energy conservation techniques may result in savings of $46 \%$ (Testi et al., 2017), besides controlling the operation of the Heating, Ventilation, and Air Conditioning (HVAC) system as well as arranging the operation of the lighting system. Based on research conducted on an educational building in Saudi Arabia, operating the HVAC and lighting systems lead to $21.1 \%$ and $14.3 \%$ annual energy savings, respectively (Hamida et al., 2021).

Many factors influence the efficiency of school buildings, such as insulation, U-value of glazing, shading element, building 
orientation, and the material's heat conductivity (Yumming et al., 2018). All of this may require stage 1, 2, or 3 of energy retrofitting. There are three steps of retrofitting measures (Carbonari, 2019). The first phase is the lean energy initiatives such as energy management to ensure that the attitude and awareness of the building occupants are positive. The second phase is green technology retrofitting, such as adopting new and low carbon technology to replace or upgrade the existing traditional nonenergy-efficient electrical equipment and system (Bertone et al., 2018). The third phase is clean energy retrofitting initiatives. Guan et al. (2016) stated that clean energy retrofitting initiatives offer the greatest effectiveness in energy reduction due to different sources of energy utilization from clean or renewable energy. Phases 2 and 3 involve costs ranging from medium to high due to physically retrofitting the building elements. On the other hand, for minimal to zero cost retrofitting, Lean Energy Conservation Measures (LECMs) should be examined and implemented by the school management team (John et al., 2017).

Numerous studies found that occupant behavior plays a critical role in contributing to building efficiency, especially in bridging the gap between actual energy usage and calculated energy requirement (Franco et al., 2021). Antonio and Bacher (2018) stated that the occupancy behavior impact during the post-occupancy phase should be taken seriously. He added that building occupants who behave differently than expected will lead to buildings failing to perform as planned. Ben and Steemers (2017) stated that awareness, exposure, and knowledge are derived from positive environmental behaviors. Some examples of negative behavior patterns are leaving idle computers, lights, fans, TV, and other electrical equipment on without switching it off (Wei et al., 2017). Apart from that, irresponsible use of lights even when natural lighting is sufficient is also a common negative behavioral pattern among school students (David and William, 2017), as well as using the cooling unit such as air conditioning or fan at maximum speeds even when the surrounding temperatures are quite cold such as rainy and windy days (Bertone et al., 2018). A study by Xu et al. (2020) discovered that occupant-related variables influence electrical energy usage in educational buildings by up to $10.7 \%$, with a type of occupancy being the most relevant parameter, followed by the level of education, duration of residency, household size, income, and age. Hence, the school management needs to examine and implement key energy management measures for students to educate them in order to gain positive changes in the behavior of students.

This research aims to assess the potential for schools in Malaysia to reduce their energy consumption and propose recommendations for important LECMs to be adopted. It will include a preliminary energy consumption audit to establish a baseline for energy usage in the school (George and Jayakumar, 2019). Lean energy-saving strategies will be addressed in this study to help school management teams better understand and identify important energy management that is appropriate for their schools and can be applied for future progress. In order to attain more dependable outcomes, retrofit operations must be evaluated while taking into account the actual behavior of the occupants. These studies primarily assumed different behavioral scenarios based on the integration of various actions such as window opening, thermostat control, HVAC, and lighting operation with energy savings varying from $22 \%$ to $80 \%$ in five different case studies in the United Kingdom, the United States, Italy, and Spain (Hafner et al., 2020). Therefore, investigating students' energy consumption behaviors, raising energy conservation awareness, and adopting effective energy management strategies in schools are highly recommended $(\mathrm{Hu}$ et al., 2020).

Since education is a fundamental element of every nation, the significance of this study is to establish benchmarks for energy usage in Malaysian schools intending to achieve a sustainable school environment and comfortable learning for students (Roberts et al., 2019). Furthermore, according to the Ministry of Education Malaysia, in 2021, there are approximately 7,780 and 2,440 primary and secondary schools, respectively, approximately amounting to 10,220 schools nationwide (Ministry of Education Malaysia, 2020). Suppose there is a potential energy reduction of at least RM 100/month. Approximately RM 1,022,000.00/month cost reduction can be achieved throughout a year, assuming each school takes a proactive approach in using energy efficiently. Because of the large number of existing buildings, EE is a means of regulating and restraining the growth in energy consumption (Moazzen et al., 2020). Another significance of school building to be retrofitted is the fact that the effect of students' awareness and education about their role regarding energy consumption is noticeable especially after joining the Energy Efficiency Challenge (Jami et al., 2021). Finally, this will assist school stakeholders, particularly the Ministry of Education, in developing more energy-efficient schools in the future and instilling energy awareness among pupils.

\section{RESEARCH LEAD AND METHODS}

\section{Research Methodology}

The approach for this study is based on a case study and is carried out in a methodical manner using the proper analysis methodologies to be used in energy management (Nawi et al., 2019). In addition to experiments, surveys, histories, and archival data analysis, case studies are a method that may be utilized in social science research (Morshed et al., 2019). Furthermore, it is a field study approach in which field studies investigate events as they occur without the researcher intervening significantly (Molina-Solana et al., 2017). In addition, a case study is an empirical investigation that arises from the desire to comprehend complicated events in a real-life situation by collecting in-depth data from numerous sources.

In this research, case studies will be used to analyze the energy usage of school buildings. It entails a preliminary audit and study of utility bills that were examined prior to joining the EE Challenge in the year 2016 and after participating in the competition for four consecutive years from 2016 to 2019. To gain a further understanding of the key practices implemented in achieving energy savings, focus group discussions with professionals and school building management were undertaken. 


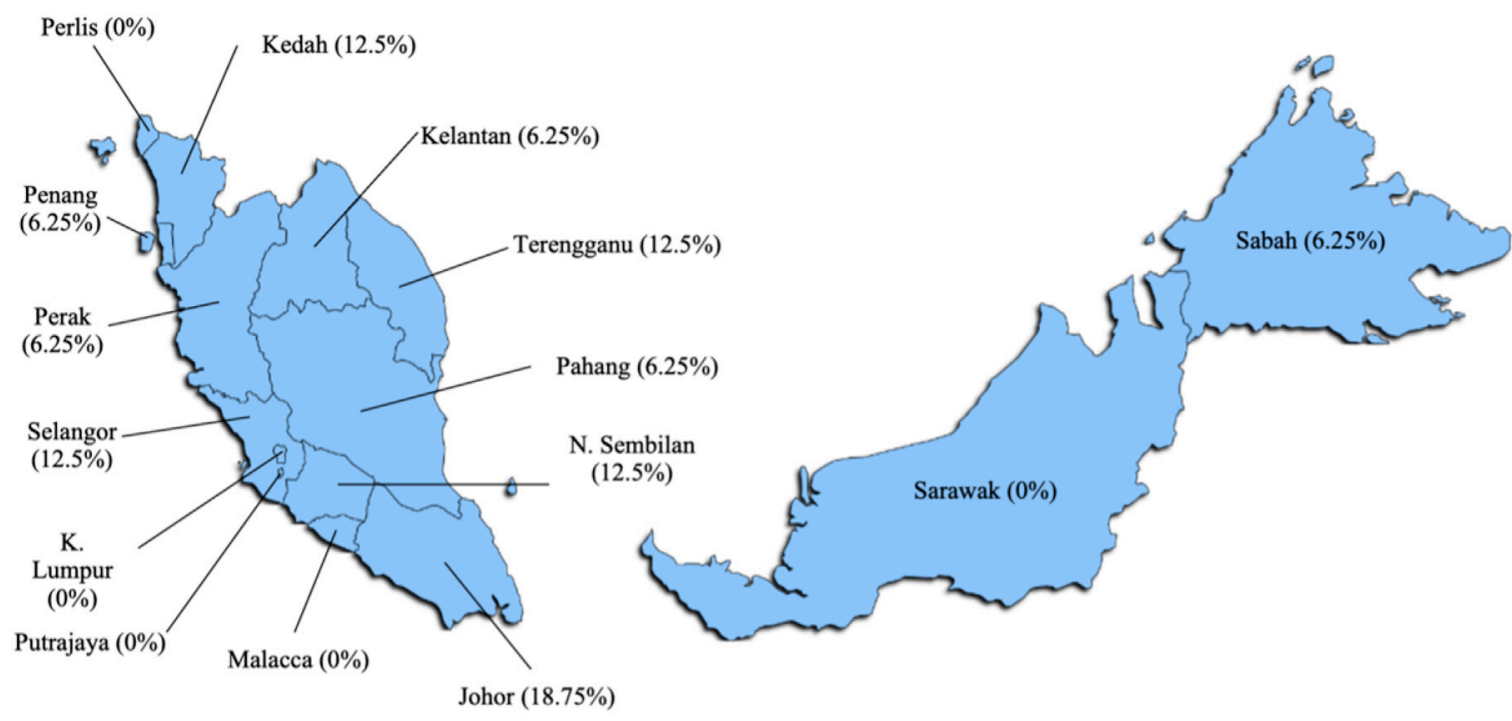

FIGURE 1 | Total number of schools participated in the Energy Efficiency Challenge from 2016 to 2019.

The frequency distribution, mean, and SD analysis were used to summarize the data gathered from the focus group discussions. The quantity and percentage of each key practice were shown in a frequency distribution value to illustrate the implementation level (Luddeni et al., 2018). Meanwhile, the mean is used to determine the central tendency of the implementation level of energy management key practices. This was used as the determining factor to rank the key practices from most applied to the least applied (AlFaris et al., 2016). Finally, the SD was utilized to demonstrate how much all of the scores in a group varied from the mean score on average.

\section{Case Study Setup}

Since the introduction of the Energy Efficiency Challenge in 2014, approximately 250 schools from all over Malaysia have participated. However, among 250 schools, only 46 schools (18.4\%) have consistently joined the competition for four consecutive years. Out of these 46 schools, 27 of these are government schools (58.7\%), and the remaining 19 are private schools (41.3\%). Among 27 government schools, only 16 schools have the traditional standard design layout. The other 11 schools have designed and built layouts with more updated design, infrastructure, and facilities. As for this research, only government schools with standard design layouts are considered a limitation of the study.

Since the 1970s, the standard design drawing plan for school buildings has been used. With that being said, it has architectural constraints and might be considered a "historic" building. The aforementioned standard design layout was approved by the Malaysian Government and implemented by the Public Work Department. Authors believe that the selected school buildings are typical Malaysian public-school buildings that require retrofit due to their traditional design layout. The data of five schools in Figure 1 were derived from the schools in the southern region of Peninsular Malaysia, Negeri Sembilan, Malacca, and Johor. This region is targeted as an area for the case study, as it has the highest school participation in the EE Challenge, which is five schools (31.25\%). Apart from that, all five schools are suitable for the case study, as they are located in the typical tropical climate of Malaysian temperature, which ranges between $22^{\circ} \mathrm{C}$ and $32^{\circ} \mathrm{C}$ with an average of $26^{\circ} \mathrm{C}$ (Zaki et al., 2017). Further limitations will be discussed later under the limitations section of this study.

\section{Focus Group Discussion}

In this study, the primary data collection was done through focus groups. Focus groups were chosen over other qualitative research methodologies, as they provide insightful information on the participants' collective perspectives on essential energy management techniques. This technique assists in the development of a comprehensive understanding of participants' experiences and perspectives. Morshed et al. (2019) employed the same methodologies in their study on retrofitting obstacles and strategies to overcome similar issues. The presence and interaction of the participants brought a different dynamic impact on the focus group discussion. This is especially essential in this study to understand the key energy management techniques of several participants who work in different organizations of the government.

The criteria for selecting focus group members were that they must be prominent government officials and have at least 10 years of building retrofitting, green project development, and management expertise. The focused group began with a brief overview of the study topic, objectives, and discussion regarding the best practices for energy management efficiency in public school buildings. Then there was a 1-h session involving comprehensive discussions that addressed a wide range of retrofitting subjects, including current sustainable issues, project samples, and EE matters in schools. The conversations were documented and then transcribed for analysis. 
TABLE 1 | List of actions implemented by the school authority.

School energy management key practices

\begin{tabular}{cc} 
Average mean & Standard deviation \\
\hline 1.90 & 0.308 \\
1.75 & 0.444 \\
1.75 & 0.444 \\
1.70 & 0.470 \\
1.65 & 0.489 \\
1.65 & 0.489 \\
1.55 & 0.510 \\
& \\
1.50 & 0.513 \\
1.45 & 0.510 \\
1.40 & 0.503 \\
1.30 & 0.470 \\
1.25 & 0.444 \\
1.20 & 0.410 \\
1.20 & 0.410 \\
1.15 & 0.366 \\
1.10 & 0.308 \\
1.05 & 0.224 \\
&
\end{tabular}

Certificate award "Energy Efficient Icon" to the most perform classroom

Awareness program on energy saving and sustainable living lab

Establishment of green team/task force

School cleaning activity on electrical appliances

Sticker labelling notice on irresponsible to energy reduction

Signboard notice to save energy

"Zoning" room according to energy consumption level (red label for high consumption, yellow label for medium, and green

label for low)

H Energy counselling session for students

Promote recycle program

Announcement reminder regarding energy saving during assembly

Banners and posters display around school classroom and student center

Curriculum responsive to energy saving

Workshop on energy efficiency

Energy innovation program

Sustainable theme poster e.g., drawing competition

Energy efficient theory in curriculum

Energy efficient design competition
The lists of important energy management techniques generated in this study are based on the readings and findings of various materials and sources (Karunakaran and Verayiah, 2018). It will also retrieve any relevant data for essential energy management techniques. With the use of this analytic technique, the topics that recurred the most were classified as critical criteria. One of the most prevalent principles for creating a pattern is repetition (MacNaughton et al., 2017). However, attention was made to ensure that the found criteria were related to the study topic. The results of the focus group discussions were then retrieved and evaluated in order to determine the relative importance of each criterion. There were two participants from the Energy Commission, three participants from the Malaysian Green Technology and Climate Change Centre (GreenTech Malaysia), three participants from the Malaysian Carbon Reduction and Environmental Sustainability Tool (MyCREST), and five participants from the Public Work Department, with a total of thirteen participants. Due to confidentiality and anonymity, the names of the personnel will not be disclosed.

\section{DISCUSSION}

There are two phases involved in this study. The first phase entails the analysis of key practices in school management, while the second phase is determining the schools' energy use pattern to establish the current state of its energy consumption. Mathematical equations utilized in this investigation are explained in this section.

\section{Energy Management Key Practices}

This study involved five government schools located in the south of Malaysia located in Johor and Melaka. Negeri Sembilan was not on the list, as there is not a single school from that state that joined the EE Challenge. Table 1 shows the implementation level of the management's key practices in schools during their participation in the competition. Based on the in-depth discussion with professionals from a government organization and management officers from school management who participated in the competition, there are nineteen key practices identified. These key practices are sorted, from most frequently implemented to the least, as tabulated in Table 1.

The key practice of energy management that is executed best by the school management is "energy-efficient econ award to the top-performing classroom." The classroom that achieved the highest Key Performance Indicator (KPI) for each month will be declared as the winner. The winner will be announced, and awards and rewards will be given as incentives and motivation. Each classroom will try to compete to do their best and gain the most points by following the checklist provided by the school management. Checklists and points may vary for each school.

This was then followed by an "awareness program on energy saving and sustainable living lab." It is important to note that awareness plays an important role for green schools to be accomplished (Omar et al., 2020). A study by Çakirlar Altuntaş and Turan (2018) showed the students' different levels of understanding of sustainable and environmental issues. Hence, such awareness programs must take place for educational purposes. This was then followed by the "establishment of green team/task force." The main purpose of this team is to ensure that any rules and policies regarding a sustainable environment will be monitored and enforced by the task force team for successful implementation.

"School cleaning activity on electrical appliances" and "sticker labeling notice on responsible use to energy reduction" rank third on the list. Electrical appliances should be cleaned regularly to ensure the operating process is in optimal condition. For instance, the ceiling fan will spin slowly if dust accumulates on the fan blade's surfaces; thus, this will decrease the cooling efficiency yet use the same amount of energy to operate. As a result, the same 
TABLE 2 | Background data of the schools.

\begin{tabular}{|c|c|c|c|c|c|}
\hline Name of school & SMK Pasir Gudang & $\begin{array}{l}\text { SMK Tengku Aris } \\
\text { Bendahara }\end{array}$ & $\begin{array}{l}\text { SMK Sultanah Engku Tun } \\
\text { Aminah }\end{array}$ & $\begin{array}{l}\text { SMK Bukit } \\
\text { Mewah }\end{array}$ & $\begin{array}{l}\text { SMK Raja } \\
\text { Jumaat }\end{array}$ \\
\hline ID name & S1 & S2 & S3 & S4 & S5 \\
\hline Total gross floor area $\left(\mathrm{m}^{2}\right)$ & 11,077 & 10,492 & 9,253 & 12,501 & 8,681 \\
\hline No of classrooms & 21 & 28 & 16 & 34 & 25 \\
\hline Average number of students & 1,450 & 1,300 & 750 & 2,100 & 1,100 \\
\hline Average number of staff & 130 & 110 & 80 & 140 & 90 \\
\hline
\end{tabular}

energy consumption is being used for a slower spinning fan as the ceiling fan cannot operate efficiently. To counteract this issue, labeled stickers of notice were pasted around school building common areas such as corridor, classroom doors, wall, and nearby switches socket outlet to serve as a reminder for students to always switch off lights, fans, and air conditioners when no longer in use.

The next in rank is "zoning room according to energy consumption level." Color stickers can be placed inside the classroom, office, library, computer room, curriculum room, and any compartment room within the school building by their energy consumption level. The color can range from green to indicate low consumption, yellow for medium consumption, and red for high consumption. The sticker label can illustrate and notify its users regarding a specific room compartment, thus reminding them to always be aware of energy usage, especially in the red labeled compartment.

The next eight key practices are "energy counseling session for students," "recycling program," "announcement reminder regarding energy saving during assembly," "sustainable theme poster," and so on. All of these criteria can be said as part of environmental education. The public is being taught to engage actively in environmental initiatives and help promote the smart use of natural resources for long-term sustainability (David and William, 2017). Over the last 25 years, environmental education has promoted environmental awareness, knowledge, and positive attitudes, which in turn causes the behavior of the public to be increasingly refined towards a sustainable environment mindset.

The last two key points, which are "energy innovation program" and "energy-efficient design competition," rank as the lowest two criteria implemented by the school management, with an average mean score of 1.10 and 1.05 correspondingly. This is due to the fact that these programs require the active participation of students, as there is a close relationship between awareness and the willingness of students to be part of environmental programs. Saraiva et al. (2019) indicated that the awareness level of school students is still low compared with that of teachers. This is due to the factors such as young age and lack of exposure. However, there is plenty of room for enhancement, as behavioral improvement is more possible to be implemented among students rather than among the workingclass public.

According to the rank of key implementation by the school management, most of the upper-tier criteria are done by the teachers, officers, or schools' management teams. This is in line with the study of Trianni et al. (2019), which found that gaining top management commitment is an important factor in energy management practices in the educational building. It is the most critical key practice among 47 criteria analyzed in their studies.

\section{Actual Energy Usage}

Tables 2 and 3 reveal the school's background information and the electrical equipment in use. Data presented in the tables will be used to analyze the school's current energy usage by calculating the yearly energy consumption and intensity.

Actual energy consumption is the amount of power consumed based purely on utility bills. On the other hand, the calculated energy requirement is the amount of power that the school should consume under optimal conditions, as determined by the data obtained. Table 4 displays a summary of annual energy usage derived from utility bills, as well as the pre-retrofit and postretrofit of yearly estimated energy requirements. The school's calculated energy requirements will be compared with the actual energy usage. It is also important to note that the power tariff in 2016 was RM $0.48 / \mathrm{kWh}$, that of 2017 and 2018 was RM 0.45/ $\mathrm{kWh}$, and that of 2019 was RM $0.49 / \mathrm{kWh}$. This electricity tariff change was taken into account in the calculation used for this study.

\section{Energy Requirement Calculation}

A comparison can be made between the actual energy usage obtained from utility bills with calculated energy requirements to determine if the energy usage was efficient. The following equation is used to compute the efficient energy usage of the electrical equipment in the school.

$$
A E C^{\alpha}=U H^{\alpha} \times C^{\alpha} \times L F^{\alpha}
$$

where $\mathrm{AEC}^{\alpha}$ is the annual energy consumption of equipment $\alpha$ in $\mathrm{kWh} ; \mathrm{UH}^{\alpha}$ the usage hours of the equipment $\alpha ; \mathrm{C}^{\alpha}$ the capacity of power rating of equipment $\alpha$ in $\mathrm{kW}$; and LF the loading factor of equipment $\alpha$. The loading factor for all the electrical equipment was set to 1 to model a worst-case scenario.

Building performance is defined variously by experts and researchers, which characterizes it as being connected to the building's energy usage. This study refers to building performance with the overall energy consumption throughout the year. It is critical to identify a performance index to compare the energy usage of one building with another. One of the common practices to measure energy 
TABLE 3 | Summary list of electrical equipment in schools.

\begin{tabular}{|c|c|c|c|c|c|c|c|c|}
\hline \multirow[t]{2}{*}{ Equipment type } & \multirow[t]{2}{*}{ Equipment Watts (W) } & \multicolumn{5}{|c|}{ Equipment Watts (W) } & \multirow{2}{*}{$\begin{array}{c}\text { Pre-retrofit } \\
\text { operating hours }\end{array}$} & \multirow{2}{*}{$\begin{array}{l}\text { Post-retrofit } \\
\text { operating hours }\end{array}$} \\
\hline & & S1 & S2 & \$3 & \$4 & S5 & & \\
\hline $\mathrm{A} / \mathrm{C}$ & 1,500 & 26 & 19 & 15 & 29 & 17 & 11 & 10 \\
\hline Amplifier & 250 & 2 & 2 & 1 & 3 & 1 & 11 & 8 \\
\hline Desktop computer & 200 & 34 & 30 & 23 & 38 & 27 & 11 & 10 \\
\hline Fan & 75 & 78 & 99 & 60 & 115 & 80 & 11 & 10 \\
\hline Fax & 100 & 2 & 2 & 1 & 3 & 2 & 11 & 10 \\
\hline Fridge & 100 & 3 & 3 & 3 & 3 & 4 & 11 & 10 \\
\hline Kettle & 1,850 & 3 & 4 & 2 & 4 & 2 & 7 & 5 \\
\hline Lights & 36 & 186 & 224 & 146 & 251 & 173 & 11 & 10 \\
\hline Microwave & 800 & 2 & 2 & 1 & 2 & 1 & 11 & 5 \\
\hline Photocopier & 1,300 & 2 & 2 & 2 & 5 & 3 & 11 & 10 \\
\hline Printer & 120 & 10 & 9 & 5 & 12 & 7 & 11 & 10 \\
\hline Pump 1 & 370 & 1 & 1 & 1 & 1 & 1 & 11 & 10 \\
\hline Pump 2 & 1,500 & 1 & 1 & 1 & 1 & 1 & 11 & 10 \\
\hline Rice cooker & 400 & 2 & 2 & 1 & 3 & 1 & 7 & 5 \\
\hline Stand fan & 50 & 3 & 3 & 1 & 8 & 3 & 11 & 10 \\
\hline TV & 150 & 2 & 2 & 2 & 3 & 2 & 11 & 5 \\
\hline Wall fan & 35 & 10 & 8 & 4 & 12 & 6 & 11 & 5 \\
\hline
\end{tabular}

load is using Building Energy Index (BEI) as a standard measurement mathematical model to evaluate energy consumption in buildings, which are commonly expressed in $\mathrm{kWh} / \mathrm{m}^{2} /$ year (Lizana et al., 2018). The building will be compared using Gross Floor Area (GFA) as a normalizing factor (Al-Khatatbeh and Ma'Bdeh, 2017). Based on the normalizing factor, the index is used to compare building energy consumption monthly or yearly by applying the following formula (Bakar et al., 2015)

$$
B E I=\frac{\text { Energy Input }(\boldsymbol{k W h})}{\text { Gross Floor Area }\left(\mathrm{m}^{2}\right)}
$$

\section{Usage Hours of Electrical Equipment}

The amount of electrical equipment used depends on the operating hours of the school, assuming that every time the school operates, the students and teachers start to use the equipment available. In Malaysia, schools operate five times a week from Monday to Friday for teaching. Additional utilization may occur on selected weekends for curricular activities. All five case studies have both morning and afternoon sessions, where the morning session starts from 7: 30 a.m. to 1:00 p.m. and the afternoon sessions start at 1:00 p.m. and end at 6:30 p.m.; both have 20-min recess break. These schools operated for 263 days in 2016, 251 days in 2017, 257 days in 2018, and 259 days in 2019. According to the schools, $11 \mathrm{~h}$ per day is the general operating hours of the school, which includes both the morning and afternoon sessions, which are also the usage hours of the electrical equipment. However, some of the pieces of equipment are only used for $7 \mathrm{~h}$ per day during the pre-retrofit period. During the post-retrofit period, usage of most of the pieces of equipment has been reduced to $10 \mathrm{~h}$, while usage of some has a further reduction, where they are used for 5 and $8 \mathrm{~h}$ per day as tabulated in Table 3. A comparison of the actual electricity usage is used to validate whether the school utilized its electricity efficiently or otherwise.

\section{RESULT COMPARISON}

All the pieces of electrical equipment are assumed to be operating at maximum loading factor and follow the assumption operating hours $(11 \mathrm{~h} /$ day $)$. Undoubtedly, the assumption made was overvalued, but preparing for the worst-case scenario is the best assumption for this study.

Table 4 demonstrates the summary of energy consumption per year across the five schools, according to 4 years' data of schools of the years 2016-2019. The year 2016 has the peak and gradually decreases as it approached 2019. This gives a good indicator that the energy consumption is going down for all five schools. Table 4 shows that all schools have increased their total cost in 2019 after it has been decreasing from 2016 to 2018. This is due to the increase of tariff from RM $0.45 / \mathrm{kWh}$ to RM $0.49 / \mathrm{kWh}$. An increase of RM $0.04 / \mathrm{kWh}$ has a significant difference, especially when dealing with huge energy consumption over a year's period.

It is clear to see in S4 that the highest energy consumption reached almost the mark of $300,000 \mathrm{kWh} /$ year in 2016 . On the other hand, S3 shows the peak at only $170,564 \mathrm{kWh} /$ year in the same year. The number of students plays an important role, where S4 shows an average of 2,100 students while S3 only shows 750 . Having more students in a school will mean that more classes and that more pieces of equipment are to be utilized, thus increasing the demand for more energy. In terms of actual electricity cost, S4 records RM 142,707 in 2016 with the calculated requirement cost of RM 126,909 with a difference of RM 15,804. However, in 2019, a difference of only RM 2,782 shows excellent improvement in terms of usage efficiency. The biggest difference between actual electricity usage and calculated electricity requirement in the year 2016 is displayed in S5. A difference of RM 39,344 indicates how inefficient energy was used as shown in S5 in that particular year. However, this cost gradually decreases to only RM 9,406, which is $76 \%$ in 4 years in terms of efficiency usage. 
TABLE 4 | Summary of yearly energy usage from utility bills, pre-retrofit calculated energy requirement, and post-retrofit calculated energy requirement.

\begin{tabular}{|c|c|c|c|c|c|c|}
\hline School & $\begin{array}{l}\text { Actual electricity } \\
\text { usage (kWh/year) }\end{array}$ & $\begin{array}{l}\text { Actual usage } \\
\text { cost (RM/ } \\
\text { year) }\end{array}$ & $\begin{array}{l}\text { Pre-retrofit calculated } \\
\text { electricity requirement } \\
\qquad(\mathbf{k W h} / \text { year) }\end{array}$ & $\begin{array}{l}\text { Pre-retrofit calculatedusage cost } \\
\text { (RM/year) }\end{array}$ & $\begin{array}{l}\text { Post-retrofit calculated } \\
\text { electricity requirement } \\
\text { (kWh/year) }\end{array}$ & $\begin{array}{l}\text { Post-retrofit } \\
\text { calculated usage } \\
\text { cost (RM/year) }\end{array}$ \\
\hline \multicolumn{7}{|l|}{ S1 } \\
\hline 2016 & 248,539 & 119,299 & 213,405 & 102,434 & 182,433 & 87,568 \\
\hline 2017 & 237,329 & 106,798 & 210,159 & 94,572 & 179,658 & 80,846 \\
\hline 2018 & 229,211 & 103,145 & 208,536 & 93,841 & 178,271 & 80,222 \\
\hline 2019 & 219,342 & 107,478 & 203,668 & 99,797 & 174,109 & 85,313 \\
\hline \multicolumn{7}{|l|}{ S2 } \\
\hline 2016 & 219,449 & 105,336 & 194,031 & 93,135 & 162,479 & 77,990 \\
\hline 2017 & 207,587 & 93,414 & 191,080 & 85,986 & 160,008 & 72,004 \\
\hline 2018 & 205,875 & 92,644 & 189,604 & 85,322 & 158,772 & 71,447 \\
\hline 2019 & 199,113 & 97,565 & 185,178 & 90,737 & 155,065 & 75,982 \\
\hline \multicolumn{7}{|l|}{ S3 } \\
\hline 2016 & 170,564 & 81,871 & 138,766 & 66,608 & 118,997 & 57,119 \\
\hline 2017 & 164,117 & 73,853 & 136,655 & 61,495 & 117,187 & 52,734 \\
\hline 2018 & 157,890 & 71,051 & 135,600 & 61,020 & 116,282 & 52,327 \\
\hline 2019 & 151,705 & 74,335 & 132,434 & 64,893 & 113,567 & 55,648 \\
\hline \multicolumn{7}{|l|}{ S4 } \\
\hline 2016 & 297,306 & 142,707 & 264,394 & 126,909 & 225,407 & 108,195 \\
\hline 2017 & 280,043 & 126,019 & 260,373 & 117,168 & 221,979 & 99,891 \\
\hline 2018 & 271,662 & 122,248 & 258,362 & 116,263 & 220,264 & 99,119 \\
\hline 2019 & 266,051 & 130,365 & 252,331 & 123,642 & 215,122 & 105,410 \\
\hline \multicolumn{7}{|l|}{ S5 } \\
\hline 2016 & 201,780 & 96,854 & 162,436 & 77,969 & 140,424 & 67,404 \\
\hline 2017 & 190,891 & 85,901 & 159,966 & 71,985 & 138,288 & 62,230 \\
\hline 2018 & 182,101 & 81,945 & 158,730 & 71,429 & 137,220 & 61,749 \\
\hline 2019 & 169,372 & 82,992 & 155,025 & 75,962 & 134,016 & 65,668 \\
\hline
\end{tabular}

S1 and S2 have the most similarities in terms of graph trends. However, the overall graph data shown in S1 are still higher than those in S2 due to a slightly greater number of students, teachers, and electrical equipment. Hence, there was also a slightly higher electricity demand. The actual cost shown in S1 in 2016 was RM 119,299 , which was reduced to RM 107,478 in 2019 , with a $9 \%$ reduction. Compared with the calculated requirement cost, in 2016 , there is a difference of $14.14 \%$, while in 2019 , the difference is $4.19 \%$. The efficiency difference shown in S1 from 2016 to 2019 is $9.95 \%$ in 4 years' time. On the other hand, S2 shows that the difference went down from RM 105,336 in 2016 to RM 97,565 in 2019 , with a $7 \%$ reduction. In 2016 , the actual and calculated cost difference was $11.58 \%$ more than the $10 \%$ difference in efficiency. However, in 2019 , the changes were reduced to $4.03 \%$ only with a $7.55 \%$ efficiency improvement in terms of cost.

Table 4 shows that the average post-retrofit calculated electricity requirement is lower than the actual, and the pre-retrofit calculated electricity requirement. Post-retrofit calculated energy demand achieved energy savings of approximately $14.14 \%-17.62 \%$ reduction when compared with the pre-retrofit electricity usage while achieving higher savings of $26.50 \%-32.41 \%$ when compared with the actual electricity usage in all schools. It indicates that an average of $29.46 \%$ energy usage can be further reduced with improved efficient usage of the equipment in schools. However, since the actual electricity usage from all schools in 2016-2019 gradually decreased, the $29.46 \%$ benchmark is an achievable goal in the long run given that these schools have only been practicing $\mathrm{EE}$ for 4 years. The post-retrofit calculated consumption is in line with the actual electricity usage, pre-retrofit, and post-retrofit calculated electricity requirement where the trend continuously decreases throughout the year, indicating the effectiveness of energy conservation measures implemented.

Figure 2 illustrates the summary of the BEI for three categories, which are actual BEI, pre-retrofit calculated BEI, and post-retrofit calculated BEI in $\mathrm{kWh} / \mathrm{m}^{2} /$ year based on the same schools throughout the 4 years' period. Figure 2 shows the BEI with more balanced graphs, as this is due to the factor of GFA. The bigger the school's GFA, the more students and teachers will enroll in the school, for instance, as shown in S4. On the other hand, schools with smaller GFA will have fewer students enrolled and teachers as tabulated in Table 4. However, not all classrooms will accommodate the same number of students, for instance, 30 students per class. Usually, students will enroll at the school according to the address on their Identity Card (IC). The higher the density of citizens in the area, the more likely students will enroll. Comparisons can be seen between S1 and S4; for example, a GFA of $11,077 \mathrm{~m}^{2}$ accommodates 1,450 students, as shown in S1. On the other hand, with an additional $1,424 \mathrm{~m}^{2}, \mathrm{~S} 2$ has to accommodate an additional 650 students, as they will cram more students per class and the school holistically, thus impacting energy usage, as seen in Table 4.

\section{Limitations}

All case studies are located in an area of a typical tropical Malaysian climate where the temperatures typically range from 


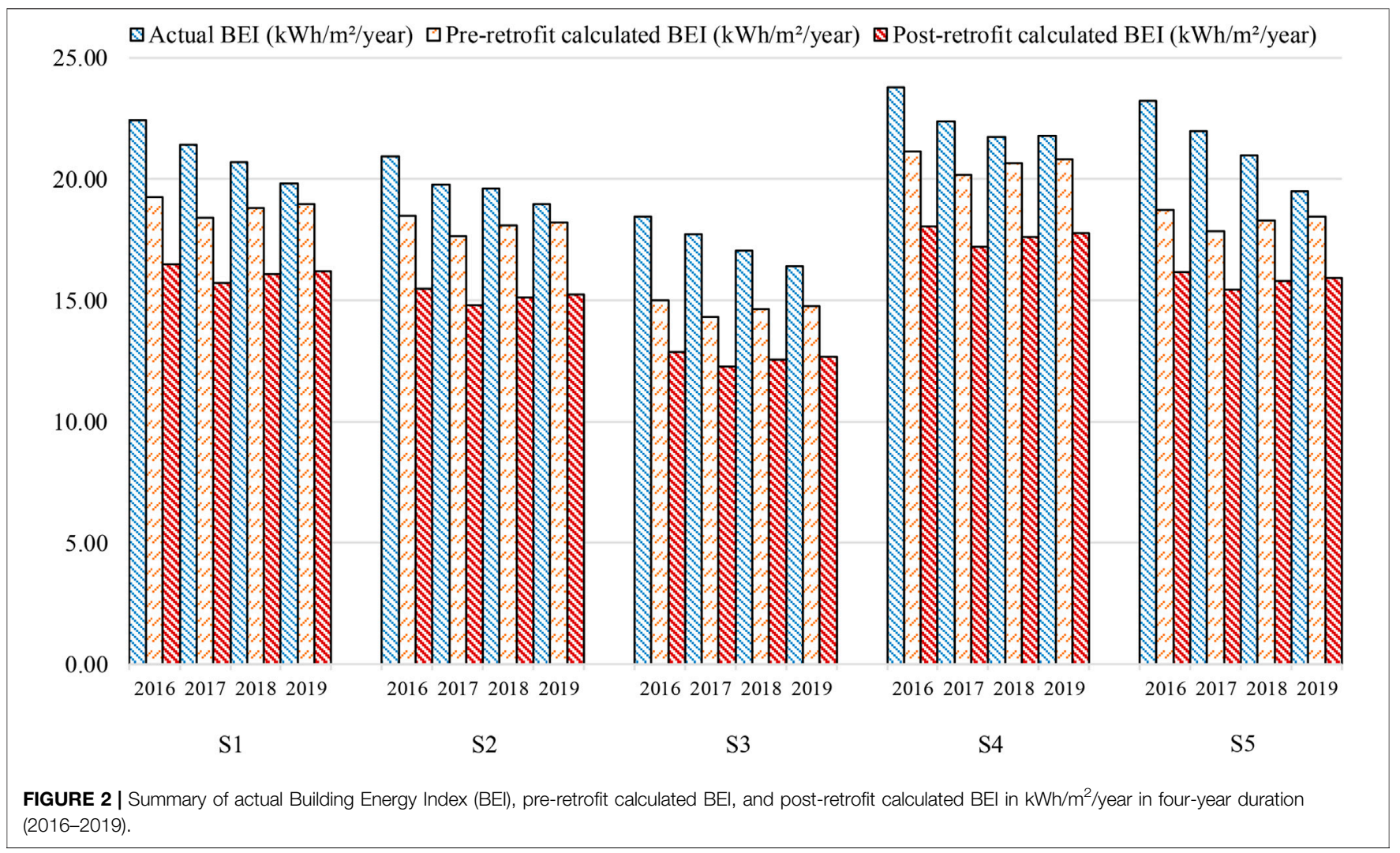

$22^{\circ} \mathrm{C}$ to $32^{\circ} \mathrm{C}$ with an average of $26^{\circ} \mathrm{C}$. School buildings located in lower-average-temperature areas such as the schools in Genting Highlands and Fraser Hills, which have average temperatures of $19^{\circ} \mathrm{C}-22^{\circ} \mathrm{C}$, were not accounted for in these case studies. Lower ambient temperature reflects different occupants' behavior, temperature, and wellbeing. A total of 10,220 schools are currently governed by the Malaysian Government, which falls under the responsibility of the Ministry of Education. The ministry is in charge of the school management, dress code, law, curriculum program, and standard operating procedures, as well as expenses on maintenance, renovation, and utility. However, there are 523 schools that self-governed their expenses. International schools, religious schools, academic primary schools, and secondary primary schools are among those that fund their own expenses through fees collected from their students. These self-governed schools are excluded from the scope of this study mainly due to nonstandard school building design, electrical equipment, and operating hours of the schools.

Only standard school design drawing layout approved by the Malaysian Government, monitored and implemented by Public Work Department, has been taken into account. The standard drawing design needs to be followed by contractors in building government schools. It could range from one to four floor levels. The dimension of a floor is a standard 7,500-mm width excluding corridors. The length varies from 45,000 up to $90,000 \mathrm{~mm}$ or even more depending on the enrolment of students in the area. For a high-density population, the design could be four blocks of four levels with a 72,000-mm length span. Perhaps for a less dense population, the design could be two blocks of three levels with a $54,000-\mathrm{mm}$ length span. This study is only applicable to the same design layout of government schools. For schools that vary from the standard design, this study may not be applicable, as they have different construction material specifications, ceiling heights, window opening sizes and types, number and type of electrical equipment (different Watts), and even operating hours. These factors will affect the total energy consumption between government and private schools. Thus, this study is limited only to schools with standard Malaysian Government design drawing layout.

There are many retrofit approaches currently available to improve the energy performance of a building. This study focuses on three phases of retrofitting initiatives, which are lean, green, and clean retrofit initiatives. Lean retrofit initiatives refer to passive design measures, such as optimizing orientation, ventilation, lighting, shading, and energy management. Besides that, this retrofit initiative refers to the inspection, analysis, and optimization of the building envelope as well as ensuring its electrical equipment works efficiently. Green technology retrofit is the implementation of technologies that have low energy consumption and carbon as an alternative to supplying energy efficiently. Lastly, clean energy retrofit is associated with obtaining and supplying energy from renewable sources to minimize residual carbon emissions. It has a high cost for implementation with high efficiency and energy reduction. 
This study is limited to energy management under the first phase of retrofit initiatives. Choong et al. (2012) have done key implementation in energy management practice in Malaysian Universities instead of a school building. However, there are numerous studies found by other researchers who focused on school buildings previously, especially in implementing retrofit initiatives. Umberto et al. (2017) discussed retrofit measures being done, such as adding wall external insulation, window replacement with double glazing low-E, ceiling insulation, installation of LED lighting, solar protection, and insulation under cantilevered floors for school buildings in Catalonia, Spain. Besides that, the study byTesti et al. (2017) discussed retrofit action implemented such as installation of water-source heat pump, installation of solar thermal panels, installation of a photovoltaic (PV) system, installation of venetian blinds, external insulation of roofs, external insulation of walls, and replacement of windows. A whopping RM 4.96 million has been spent, and $43 \%$ of electric energy usage has been saved after the retrofit. Another study by Tsikra and Andreou (2017)discussed the installation of ceiling fans, external shading of the openings, application of additional insulation internally, application of insulation under the roof of the building, and application of low-E glass on windows.

\section{CONCLUSION}

This study shows that in 2016, there was a vast difference between actual electricity usage and calculated energy requirement. However, the difference was reduced gradually in 2017, followed by 2018, and ultimately in 2019 through the implementation of key energy conservation measures. This indicates that the efficiency of energy usage through responsible behavior and practice is improving. The findings reveal the key practice of giving recognition, award, and incentives implemented mainly through schools' management, which helped with motivating students to promote good environmental behavior. Other important key factors such as establishing a green task force team, sticker labeling, signboard notices, room zoning, counseling sessions, and announcement reminders require commitment from the schools' management. This proves that most of the upper-tier key practices need to be addressed by the top management. It is very critical for the top management to play their role to initiate, push, and develop a responsible behavior environment among students.

Furthermore, the common conception is that school students are less aware of a green and sustainable

\section{REFERENCES}

Abu Bakar, N. N., Hassan, M. Y., Abdullah, H., Rahman, H. A., Abdullah, M. P., Hussin, F., et al. (2015). Energy Efficiency Index as an Indicator for Measuring Building Energy Performance: A Review. Renew. Sust. Energ. Rev. 44, 1-11. doi:10.1016/j.rser.2014.12.018 environment, which in turn requires the teachers to guide them on the right path towards a sustainable school environment. Thus, every school must adopt core energy management practices in the operational phase to ensure that they progress towards a more energy-efficient lifestyle. Further energy studies on more Malaysian schools will provide a better and more accurate energy consumption benchmark, as there are limited studies on school buildings in Malaysia at this point in time. Most EE and retrofitting studies of the educational buildings in Malaysia focus more on universities rather than schools. Various retrofitting measures can be conducted to reduce even more energy usage, focusing around green and clean retrofit initiatives.

\section{AUTHOR CONTRIBUTIONS}

RZ, EA, and NA prepared and reviewed the final manuscript, checked the content, and revised the sequence flow of the paper presentation. AA prepared the draft of the manuscript, collected the data from the Energy Commission, and analyzed the data. NA and SN analyzed and discussed the data. AR and JK performed the English proofing and checked for plagiarism content.

\section{FUNDING}

Universiti Teknologi Malaysia Encouragement Research Grant (UTMER) Vot Q.J130000.2651.18J10.

\section{ACKNOWLEDGMENTS}

The authors would like to acknowledge the Universiti Teknologi Malaysia (UTM) and Research Management Centre on UTMER Grant Vot Q.J130000.2651.18J10 for the financial support. Furthermore, the author would like to extended gratitude to the Malaysia Energy Commission, coauthors and everyone who were directly or indirectly involved in assisting as well as supporting this research.

\section{SUPPLEMENTARY MATERIAL}

The Supplementary Material for this article can be found online at: https:/www.frontiersin.org/articles/10.3389/fbuil.2021.679579/ full\#supplementary-material

Al-Ajlan, S. A. (2018). Energy Audit and Potential Energy Saving in an Office Building in Riyadh, Saudi Arabia Journal of King Saud University. Eng. Sci. 21 (2), 65-74. Elsevier. doi:10.1016/s1018-3639(18)30510-5

Al-Khatatbeh, B. J., and Ma'bdeh, S. N. (2017). Improving Visual comfort and Energy Efficiency in Existing Classrooms Using Passive Daylighting Techniques. Energ. Proced. 136, 102-108. Elsevier B.V. doi:10.1016/ j.egypro.2017.10.294 
AlFaris, F., Juaidi, A., and Manzano-Agugliaro, F. (2016). Improvement of Efficiency through an Energy Management Program as a Sustainable Practice in Schools. J. Clean. Prod. 135, 794-805. Elsevier Ltd. doi:10.1016/ j.jclepro.2016.06.172

Antonio, P., and Bacher, J. P. (2018). The Impact of Building Occupant Behaviour on Energy Efficiency and Methods to Influence it: A Review of the State of the Art. J. Energ. 3, 1-19.

Bae, S., Martin, C. S., and Asojo, A. O. (2020). Higher Education Students' Indoor Environmental Quality Satisfaction Benchmark. Building Res. Inf. 1, 1-16. doi:10.1080/09613218.2020.1813012

Belaid, F., and Zrelli, M. H. (2019). Renewable and Non-renewable Electricity Consumption, Environmental Degradation, and Economic Development: Evidence from Mediterranean Countries. Energy Policy 133, 1-38. doi:10.1016/j.enpol.2019.110929

Belussi, L., Barozzi, B., Bellazzi, A., Danza, L., Devitofrancesco, A., Fanciulli, C., et al. (2019). A Review of Performance of Zero Energy Buildings and Energy Efficiency solutionsJournal of Building Engineering. J. Building Eng. 25, 100772, 2019 . December 2018. doi:10.1016/j.jobe.2019.100772

Ben, H., and Steemers, K. (2017). Tailoring Domestic Retrofit by Incorporating Occupant Behaviour. Energ. Proced. 122, 427-432. Elsevier Ltd. doi:10.1016/ j.egypro.2017.07.421

Bertone, E., Stewart, R. A., Sahin, O., Alam, M., Zou, P. X. W., Buntine, C., et al. (2018). Guidelines, Barriers and Strategies for Energy and Water Retrofits of Public Buildings. J. Clean. Prod. 174, 1064-1078. Elsevier Ltd. doi:10.1016/ j.jclepro.2017.11.065

Çakirlar Altuntaş, E., and Turan, S. L. (2018). Awareness of Secondary School Students about Renewable Energy Sources. Renew. Energ. 116, 741-748. Elsevier Ltd. doi:10.1016/j.renene.2017.09.034

Carbonari, A. (2019). Retrofit of Italian School Buildings The Influence of Thermal Inertia and Solar Gains on Energy Demand and Comfort', Future Cities And Environment. Ubiquity Press. Ltd. 5 (1). doi:10.5334/fce.60

Chao, V. L., Lorenzo, A. A., Saorin, J. L., and Cantero, J. D. (2020). Classroom Indoor Environment Assessment through Architectural Analysis for the Design of Efficient Schools. Int. J. Sustainableq 12, 1-12. doi:10.3390/ su12052020

Chinaza, U. (2020). Influence of Cleanliness on Learning Influence of Capabilities and Academic Performances: A South African Perspective. Int. J. Educ. Res. 8, 5934-5942.

Choong, W. W., Chong, Y. F., Low, S. T., and Mohammed, A. H. (2012). Implementation of Energy Management Key Practices in Malaysian Universities. Int. J. Emerging Sci. 2 (3), 455-477.

David, J., Erok, A., and Suparna, S. (2017). The Influence of the High School Classroom Environment on Learning as Mediated by Student Engagement. Sch. Psychol. Int. 38, 201-218. doi:10.1177/ 0143034316666413

David, J., and William, K. (2017). Impact of Occupant Behaviour on the Energy Saving Potential of Refurbishment Measures for a Public Building in the UK. Energy Building 9, 1-27. doi:10.1080/17508975.2016.1139538

Doulos, L. T., Kontadakis, A., Madias, E. N., Sinou, M., and Tsangrassoulis, A. (2019). Minimizing Energy Consumption for Artificial Lighting in a Typical Classroom of a Hellenic Public School Aiming for Near Zero Energy Building Using LED DC Luminaires and Daylight Harvesting Systems. Energy and Buildings 194, 201-217. Elsevier B.V. doi:10.1016/ j.enbuild.2019.04.033

El-Darwish, I., and Gomaa, M. (2017). Retrofitting Strategy for Building Envelopes to Achieve Energy Efficiency Alexandria Engineering Journal. Alexandria Eng. J. 56 (4), 579-589. doi:10.1016/j.aej.2017.05.011

Evangelisti, L., Guattari, C., Grazieschi, G., Roncone, M., and Asdrubali, F. (2020). On the Energy Performance of an Innovative Green Roof in the Mediterranean Climate. Energies 13, 51-63. doi:10.3390/en13195163

Franco, A., Miserocchi, L., and Testi, D. (2021). A Method for Optimal Operation of HVAC with Heat Pumps for Reducing the Energy Demand of Large-Scale Non Residential BuildingsJournal of Building Engineering. J. Building Eng. 43 (August), 103175. doi:10.1016/j.jobe.2021.103175

George, J. S., and Jayakumar, K. N. (2019). Does Education Enhance Employee Green Behaviour? A Study on University Faculty Members. Int. J. Basic Appl. Res. 9 (6), 491-498. doi:10.1504/mejm.2021.10036250
Geraldi, M. S., Gnecco, V. M., Barzan Neto, A., Martins, B. A. d. M., Ghisi, E., Fossati, M., et al. (2021). Evaluating the Impact of the Shape of School Reference Buildings on Bottom-Up Energy Benchmarking. J. Building Eng. 43 (July), 103142. doi:10.1016/j.jobe.2021.103142

Guan, J., Nord, N., and Chen, S. (2016). Energy Planning of University Campus Building Complex: Energy Usage and Coincidental Analysis of Individual Buildings with a Case Study. Energy and Buildings 124, 99-111. doi:10.1016/ j.enbuild.2016.04.051

Hafner, R. J., Pahl, S., Jones, R., and Fuertes, A. (2020). Energy Use in Social Housing Residents in the UK and Recommendations for Developing Energy Behaviour Change Interventions. J. Clean. Prod. 251, 1-40. doi:10.1016/ j.jclepro.2019.119643

Hamida, M. B., Ahmed, W., Asif, M., and Almaziad, F. A. (2021). TechnoEconomic Assessment of Energy Retrofitting Educational Buildings: A Case Study in Saudi Arabia. Sustainability (Switzerland) 13 (1), 1-15.

Hu, S., Yan, D., Azar, E., and Guo, F. (2020). A Systematic Review of Occupant Behaviour in Building Energy Policy. Building Environ. 175, 16-30. doi:10.1016/j.buildenv.2020.106807

Jami, S., Forouzandeh, N., Zomorodian, Z. S., Tahsildoost, M., and Khoshbakht, M. (2021). The Effect of Occupant Behaviors on Energy Retrofit: A Case Study of Student Dormitories in Tehran. J. Clean. Prod. 278, 123556, 2021 . Elsevier Ltd. doi:10.1016/j.jclepro.2020.123556

Jiang, J., Wang, D., Liu, Y., Xu, Y., and Liu, J. (2018). A Study on Pupils' Learning Performance and thermal comfort of Primary Schools in China. Building Environ. 134, 102-113. Building and Environment. doi:10.1016/ j.buildenv.2018.02.036

John R. Kilbourne, R. K., Lennie Scott-Webber, S. W., and Laura R. Kapitula, R. K. (2017). An Activity-Permissible Classroom: Impacts of an Evidence-Based Design Solution on Student Engagement and Movement in an Elementary School Classroom. Child. Youth Environments 27, 112-134. doi:10.7721/ chilyoutenvi.27.1.0112

Kamaruzaman, S. N., Egbu, C. O., Mahyuddin, N., and Ahmad Zawawi, E. M. (2017). The Impacts if IEQ on Occupants' Satisfaction in Malaysia Buildings. Indoor Built Environ. 27, 715-725.

Karunakaran, S., and Verayiah, R. (2017). Criteria for Green School Model Development in Malaysia. Int. J. Eng. Tech. 5 (7), 1-6.

Karunakaran, S., and Verayiah, R. (2018). Framework for Green School Model Development in Malaysia. Int. J. Eng. Tech. 7 (4), 442-448. doi:10.14419/ ijet.v7i4.35.22859

Khalil, N., Husin, H. N., and Nawawi, A. H. (2018). Evaluation and Concept of Building Performance towards Sustainability in Malaysian Higher Institutions. ajE-Bs 3, 91-99. doi:10.21834/aje-bs.v3i6.239

Li, P., Froese, T. M., and Brager, G. (2018). Post-occupancy Evaluation: State-OfThe-Art Analysis and State-Of-The-Practice Review. Building Environ. 133, 187-202. doi:10.1016/j.buildenv.2018.02.024

Lizana, J., Serrano-Jimenez, A., Ortiz, C., Becerra, J. A., and Chacartegui, R. (2018). Energy Assessment Method towards Low-Carbon Energy Schools. Energy 159, 310-326. Elsevier Ltd. doi:10.1016/j.energy.2018.06.147

Luddeni, G., Krarti, M., Pernigotto, G., and Gasparella, A. (2018). An Analysis Methodology for Large-Scale Deep Energy Retrofits of Existing Building Stocks: Case Study of the Italian Office Building. Sust. Cities Soc. 41, 296-311. December 2017. doi:10.1016/j.scs.2018.05.038

MacNaughton, P., Satish, U., Laurent, J. G. C., Flanigan, S., Vallarino, J., Coull, B., et al. (2017). The Impact of Working in a green Certified Building on Cognitive Function and Health. Building Environ. 114, 178-186. doi:10.1016/j.buildenv.2016.11.041

Marrone, P., Gori, P., Asdrubali, F., Evangelisti, L., Calcagnini, L., and Grazieschi, G. (2018). Energy Benchmarking in Educational Buildings through Cluster Analysis of Energy Retrofitting. J. Energ. 11, 114-134. doi:10.3390/en11030649

Mazlan, A. N., Saad, S., Yahya, K., Haron, Z., Hasbollah, D. Z. A., Kasiman, E. H., et al. (2020). "Thermal Comfort Study for Classroom in Urban and Rural Schools in Selangor," in IOP Conference Series: Materials Science and Engineering (Langkawi, Malaysia), 1-8. doi:10.1088/1757-899x/849/1/012016

Meiboudi, H., Lahijanian, A., Shobeiri, S. M., Jozi, S. A., and Azizinezhad, R. (2017). Development and Validation of Sustainability Criteria of Administrative green Schools in Iran. J. Environ. Manage. 197, 605-609. doi:10.1016/ j.jenvman.2017.04.045 
Merabtine, A., Maalouf, C., Al Waheed Hawila, A., Martaj, N., and Polidori, G. (2018). Building Energy Audit, thermal comfort, and IAQ Assessment of a School Building: A Case Study. Building Environ. 145 (July), 62-76. doi:10.1016/j.buildenv.2018.09.015

Ministry of Education Malaysia (2020). Statistic of School. Student \& Teachers.

Moazzen, N., Ashrafian, T., Yilmaz, Z., and Karagüler, M. E. (2020). A MultiCriteria Approach to Affordable Energy-Efficient Retrofit of Primary School Buildings. Appl. Energ. 268, 115046. Elsevier January 2018. doi:10.1016/ j.apenergy.2020.115046

Molina-Solana, M., Ros, M., Ruiz, M. D., Gómez-Romero, J., and MartinBautista, M. J. (2017). Data Science for Building Energy Management: A Review. Renew. Sust. Energ. Rev. 70, 598-609. November 2016. doi:10.1016/ j.rser.2016.11.132

Morshed, A., Zou, P. X. W., Stewart, R. A., Bertone, E., Sahin, O., Buntine, C., et al. (2019). Government Championed Strategies to Overcome the Barriers to Public Building Energy Efficiency Retrofit Projects. Sust. Cities Soc. 44 (9), 56-69.

Najafi, N., Mohaved, K., Barzegar, Z., and Samani, S. (2018). Environmental Factors Affecting Students' Stress in the Educational Environment: A Case Study of Shiraz Schools. Int. J. Sch. Health 5, 1-7. doi:10.5812/intjsh.67153

Nawi, M. N. M., Tahir, M. Z., and Yusoff, M. N. (2019). Barriers, Challenges and Opportunity for Energy Management Program: A Case Study of Universiti Utara Malaysia. J. Adv. Res. Fluid Mech. Therm. Sci. 60 (2), 258-269.

Norazman, N., Ani, A. I. C., Ismail, W. N. W., Hussain, A. H., and Maulud, K. N. A. (2021). Indoor Environmental Quality towards Classrooms' Comforts Level 1: Case Study at Malaysian Secondary School Building. Appl. Sci. 11, 1-16. doi:10.3390/app11135866

Norazman, N., Che Ani, A. I., Ja'afar, N. H., and Khoiry, M. A. (2018). Indoor Lighting in Classroom Environment Influences on Students' Learning Performance. Tjssr 6, 986-990. doi:10.32861/jssr.spi6.986.990

Omar, S., Shafie, W. M., and Ismail, R. (2020). Secondary School Teacher's Awareness on Green School Concept in Malaysia. J. Crit. Rev. 7 (17), 1-14.

Paola, M., Francesco, A., Daniela, V., Federico, O., Luca, E., Claudia, G., et al. (2021). On the Retrofit of Existing Buildings with Aerogel Panels: Energy, Environmental and Economic Issues. Energies 14 (1276), 1-22.

Rakhshan, K., and Friess, W. A. (2017). Effectiveness and Viability of Residential Building Energy Retrofits in DubaiJournal of Building Engineering. J. Building Eng. 13 (July), 116-126. doi:10.1016/j.jobe.2017.07.010

Roberts, C. J., Edwards, D. J., Hosseini, M. R., Mateo-Garcia, M., and OwusuManu, D.-G. (2019). Post-occupancy Evaluation: a Review of Literature. Ecam 26, 2084-2106. doi:10.1108/ecam-09-2018-0390

Sadick, A.-M., and Issa, M. H. (2017). Occupants' Indoor Environmental Quality Satisfaction Factors as Measures of School Teachers' Well-Being. Building Environ. 119, 99-109. doi:10.1016/j.buildenv.2017.03.045

Saraiva, T., Almeida, M., Bragança, L., and Barbosa, M. (2019). The Inclusion of a Sustainability Awareness Indicator in Assessment Tools for High School Buildings. Sustainability 11 (2), 387-398. doi:10.3390/ su 11020387

Stabile, L., Buonanno, G., Frattolillo, A., and Dell'Isola, M. (2019). The Effect of the Ventilation Retrofit in a School on CO2, Airborne Particles, and Energy Consumptions. Building Environ. 156 (January), 1-11. doi:10.1016/ j.buildenv.2019.04.001

Suhaimi, M. A., Rahman, M. A. A., Awang, M., Akasah, Z. A., and Hashim, N. (2017). Problems Associated with Indoor Air Quality (IAQ) in Classroom and Recommended Approaches. Politeknik Kolej Komuniti J. Soc. Sci. Humanities 2 (1), 24-30.
Tahsildoost, M., and Zomorodian, Z. S. (2015). Energy Retrofit Techniques: An Experimental Study of Two Typical School Buildings in Tehran. Energy and Buildings 104, 65-72. Elsevier B.V. doi:10.1016/j.enbuild.2015.06.079

Testi, D., Rocca, M., Menchetti, E., and Comelato, S. (2017). Criticalities in the NZEB Retrofit of Scholastic Buildings: Analysis of a Secondary School in Centre Italy. Energ. Proced. 140, 252-264. Elsevier B.V. doi:10.1016/j.egypro.2017.11.140

Trianni, A., Cagno, E., Bertolotti, M., Thollander, P., and Andersson, E. (2019). Energy Management: A Practice-Based Assessment Model. Appl. Energ. 235, 1614-1636. December 2018. doi:10.1016/j.apenergy.2018.11.032

Tsikra, P., and Andreou, E. (2017). Investigation of the Energy Saving Potential in Existing School Buildings in Greece. The Role of Shading and Daylight Strategies in Visual Comfort and Energy Saving. Proced. Environ. Sci. 38, 204-211. Elsevier B.V. doi:10.1016/j.proenv.2017.03.107

Umberto, B., Mauro, M., Pau, C., Felipe, P. A., Berardi, U., Manca, M., et al. (2017). "From High-Energy Demands to NZEB: The Retrofit of a School in Catalonia, Spain," in AiCARR 50th International Congress: Beyond NZEB Buildings (Matera, Italy: Elsevier), 141-150.

Wei, S., Hassan, T. M., Firth, S. K., and Fouchal, F. (2017). Impact of Occupant Behaviour on the Energy-Saving Potential of Retrofit Measures for a Public Building in the UK. Intell. Buildings Int. 9 (2), 97-106. doi:10.1080/ 17508975.2016.1139538

Wong, L. T., Mui, K. W., and Tsang, T. W. (2018). An Open Acceptance Model for Indoor Environmental Quality (IEQ). Building Environ. 142 (142), 371-378. doi:10.1016/j.buildenv.2018.06.031

Xu, Xiaoxiao., Bing, Li., and Zhengdao, C. (2020). Critical Factors of Electricity Consumption in Residential Buildings: An Analysis from the Point of Occupant Characteristics View. J. Clean. Prod. 256, 12-23. doi:10.1016/ j.jclepro.2020.120423

Yuanda, H., Wu, D., Collins, I. E., and Zhen, P. (2019). “Attaining Sustainability in Built Environment: Review of Green Retrofit Measures for Existing Buildings," in Earth and Environmental Science, 1-11.

Yumming, L., Tingting, L., Sudong, Y., Yisheng, L., Liu, Y. Y., Liu, T., et al. (2018). Cost-benefit Analysis for Energy Efficiency Retrofit of Existing Buildings: A Case Study in China. J. Clean. Prod. 177, 493-506. Elsevier Ltd.

Zaki, S. A., Damiati, S. A., Rijal, H. B., Hagishima, A., and Abd Razak, A. (2017) Adaptive thermal comfort in university Classrooms in Malaysia and Japan. Building Environ. 122, 294-306. Elsevier Ltd. doi:10.1016/ j.buildenv.2017.06.016

Conflict of Interest: The authors declare that the research was conducted in the absence of any commercial or financial relationships that could be construed as a potential conflict of interest.

Publisher's Note: All claims expressed in this article are solely those of the authors and do not necessarily represent those of their affiliated organizations, or those of the publisher, the editors, and the reviewers. Any product that may be evaluated in this article, or claim that may be made by its manufacturer, is not guaranteed or endorsed by the publisher.

Copyright (c) 2022 Ahamad, Abidin, Zakaria, Aminudin, Khan, Sahamir, Azman, Redzuan, Lau and Mohd Yusoff. This is an open-access article distributed under the terms of the Creative Commons Attribution License (CC BY). The use, distribution or reproduction in other forums is permitted, provided the original author(s) and the copyright owner(s) are credited and that the original publication in this journal is cited, in accordance with accepted academic practice. No use, distribution or reproduction is permitted which does not comply with these terms. 